\title{
Research
}

\section{Climate Change and Western Public Lands: a Survey of U.S. Federal Land Managers on the Status of Adaptation Efforts}

\author{
Kelli M. Archie $^{1,2,3}$, Lisa Dilling ${ }^{1,2,3}$, Jana B. Milford $^{4}$ and Fred C. Pampel $^{5}$
}

\begin{abstract}
Climate change and its associated consequences pose an increasing risk to public lands in the western United States. High-level mandates currently require federal agencies to begin planning for adaptation, but the extent to which these mandates have resulted in policies being implemented that affect on the ground practices is unclear. To examine the status of adaptation efforts, we conducted an original survey and semistructured interviews with land managers from the four major federal land management agencies in the U.S. states of Colorado, Utah, and Wyoming. The survey was designed to examine current planning for adaptation on public lands and how it differs from prior planning, the major challenges facing land managers in this region, the major barriers preventing managers from planning for adaptation, and the major hurdles associated with implementing adaptation plans. Our results show that some adaptation planning is currently taking place, but that few adaptation projects have made it to the implementation phase. Overall, respondents considered lack of information at relevant scales, budget constraints, lack of specific agency direction, and lack of useful information to be the most common barriers to adaption planning. Budget constraints, lack of perceived importance to the public, and lack of public awareness or demand to take action were reported to be the biggest hurdles to implementation of adaptation projects. Agencies showed differing levels of adaptation activity, and reported different barriers to adaptation and hurdles to implementation. Reasons for the differences and implications for future research and policy are discussed.
\end{abstract}

Key Words: adaptation; climate change; decision making; federal agencies; public lands

\section{INTRODUCTION}

Impacts of climate change are already being seen across the landscapes of the western United States. Forest ecosystems are experiencing changes in fire regimes, insect outbreaks, and tree mortality (Ryan et al. 2008). Higher temperatures and prolonged drought have led to increases in erosion and invasive species establishment in arid areas (CCSP 2008), and changes in surface temperature and precipitation patterns are reducing the livable habitat for many alpine species (Moritz et al. 2008). Federal public lands, accounting for $30-85 \%$ of the land area in each of the 12 western continental states, provide a wealth of ecosystem services ranging from recreation opportunities to water filtration and timber production (Joyce et al. 2009). In an effort to facilitate continued provision of such services federal agencies in charge of managing these lands have begun the process of adaptation to climate change (Smith and Travis 2010).

The vast majority of federal public lands in the United States are managed by four agencies: the U.S. Forest Service (USFS), the Bureau of Land Management (BLM), the National Park Service (NPS), and the U.S. Fish and Wildlife Service (FWS). A mandate to consider climate change in decision making has been in place since 2001 in the U.S. Department of the Interior, which includes the BLM, the NPS, and the FWS (Ellenwood et al. 2012). The U.S. Department of Agriculture, which houses the USFS, has had a climate change program for well over a decade that has mainly focused on research (Logar and
Conant 2007). More recently, under an Executive Order from President Obama (Executive Order 13514) and in coordination with the Interagency Climate Change Adaptation Task Force (ICCATF) all federal agencies are required to "manage the effects of climate change" (Cruce and Holsinger 2010:3) and annually submit a performance plan detailing their approach to doing so. Among other goals, the ICCATF seeks to integrate adaptation into federal government planning activities.

The literature on climate change adaptation has grown enormously in the past several years (e.g., Smit et al. 2000, Adger et al. 2007, Berrang-Ford et al. 2011). Because this study deals with federal land agencies, we will define adaptation in the same manner as the ICCATF, which is broadly consistent with the definition used by the Intergovernmental Panel on Climate Change (Adger et al. 2007). The ICCATF defines climate change adaptation as "adjustment in natural or human systems to a new or changing environment that exploits beneficial opportunities or moderates negative effects" (ICCATF 2011:2).

Despite some studies that suggest that significant barriers to adaptation may exist in U.S. federal agencies (GAO 2007, GAO 2009), adaptation efforts in federal public land agencies are beginning (Cruce and Holsinger 2010). In July of 2010 the U.S. Forest Service developed the Roadmap for Responding to Climate Change, which focuses on assessment of current situations, engagement of stakeholders, and management of

${ }^{1}$ Center for Science and Technology Policy Research (CSTPR), ${ }^{2}$ Cooperative Institute for Research in Environmental Sciences (CIRES), ${ }^{3}$ and Environmental Studies Program, University of Colorado, Boulder, ${ }^{4}$ Department of Mechanical Engineering, University of Colorado, Boulder, ${ }^{5}$ Institute of Behavioral Science, University of Colorado, Boulder 
lands for resiliency to climate change. The Roadmap includes a scorecard aimed at measuring progress and incorporating adaptation planning into Forest Service management practices (Cruce and Holsinger 2010, ICCATF 2011). In September 2010 the National Park Service responded similarly by rolling out its Climate Change Response Strategy, which includes an Adaptation and Scenario Response Program containing recommended management actions and associated goals aimed at incorporating climate change consideration across the spectrum of agency planning (Cruce and Holsinger 2010). Also in September of 2010 the U.S. Fish and Wildlife Service released an updated climate change strategy focused on adaptation and defined as a collaborative effort to maintain ecosystem functioning in the face of accelerated climate change (USFWS 2010). The Bureau of Land Management, which manages the largest number of acres of public lands in the U.S., has taken a less targeted approach to adaptation planning, but in 2010 initiated two programs, the "Proposed Landscape Approach to Management" and "Rapid Ecoregional Assessments," aimed at understanding and responding to the effects of climate change on BLM land (BLM 2010). In addition to these adaptation efforts, federal land agencies have also established emissions mitigation protocols. Though not the focus of this paper, it is important to note that greenhouse gas accounting, emissions reductions, and other mitigation efforts likely comprise a major portion of the planning and work related to climate change in this sector so far (Ellenwood et al. 2012).

These adaptation efforts within agencies, however, all represent initiatives promulgated at the headquarters level. Ultimately, to be considered effective, these policies must result in changes to decision making practices "on the ground" by agency resource managers connected with the resource in question (cf. Auld et al. 2008). The study of the process of policy implementation, which can be defined as "policy becoming action," is a worthy goal, because, as Barrett and Fudge (1981 as cited in Schofield 2001:245) point out, "policy does not implement itself." In past decades the policy implementation literature has focused on a debate as to whether top-down mechanisms such as clear policy goals and leadership or bottom-up perspectives such as individual bureaucratic discretion or public participatory processes are more important in determining how and whether a policy is implemented (deLeon and deLeon 2002). Recent syntheses suggest that both top-down and bottom-up processes have something to offer in the way of explanatory power in how policies are structured and change over time (Sabatier 2005). One of the still remaining challenges is to understand how "ordinary public services managers operationalize often ambiguous policy" (Schofield 2001:260), and what the barriers to doing so might be.

U.S. public lands agencies offer a compelling context for the study of policy implementation and the role of agents on the ground in carrying forward the goals set by national agendas. After almost a century of relative stability in U.S. public lands policy, major shifts in operational priorities and goals in public lands have occurred and are continuing. In particular, the emergence in the 1990s of environmental priorities such as preserving endangered species and managing for whole ecosystems and, even more recently, new paradigms for fire management have posed challenges to existing policy settings in public lands. Although new environmental coalitions and landmark court rulings have been important (Wood 2006), findings have also highlighted the importance of durable policy objectives such as the requirements of the Endangered Species Act (ESA) in helping to promote changes in policy settings, or rules for decision making, in federal agencies at the local level (Cashore and Howlett 2007). Research in the fire management arena also points to the role of the media, windows of opportunity, public and manager perceptions, institutional factors, and learning networks in changing policy settings in public lands agencies (Wise and Frietag 2002, Davis 2006, Calkin et al. 2011, Reiners 2012, Steelman and McCaffrey 2011).

Adaptation to climate change represents yet another area of priority that may indeed require some changes to the existing policy settings for effective implementation of policy. We therefore focus our study on the local policy context because this "settings" level is critical for the implementation and operationalizing of goals for climate change adaptation (Cashore and Howlett 2007, McDermott et al. 2009, Ellenwood et al. 2012). Others have argued, for example, that resource managers need to develop management strategies that build resilience, are more flexible, and perhaps even prepare to manage system transformation as climate changes (Joyce et al. 2009, West et al. 2009). However, little is known about how resource managers in federal public lands agencies perceive the barriers to planning and implementation of climate adaptation policy at the local level. A few recent studies have used qualitative interview data to establish perceptions of barriers to the implementation of climate change adaptation policies among land managers (Theoharides et al. 2009, Jantarasami et al. 2010, Ellenwood et al. 2012), and a 2011 study by Berrang-Ford and others reviewed a large body of literature to track adaptation efforts across a wide spectrum of institutions. Results suggest that adaptation is proceeding in some organizational contexts, although many barriers have been observed. Competing priorities, lack of relevant data, and lack of clear governmental roles have already been identified to be substantial challenges associated with climate change adaptation (GAO 2009). Lack of agency direction and lack of funding have also been previously mentioned (GAO 2007).

In this paper we provide an early study of perceptions of agency managers on progress toward implementing practices to aid with adaptation to climate change and the barriers to 
doing so on federal public lands in three western states: Colorado, Utah, and Wyoming. In addition to assessing the extent of efforts to implement adaptation policy, it is important to focus on barriers to adaptation because barriers can often be quite challenging to overcome (GAO 2009, NRC 2010). Identifying the specific barriers to adaptation for an organization can provide valuable information about the decision making context and how barriers might be overcome or lessened in number. Understanding the barriers to adaptation can also allow for more effective provisioning of resources and information to facilitate further progress in the adaptation process (Moser and Ekstrom 2010). Moser and Ekstrom (2010) have suggested a framework to systematically identify the barriers to adaptation, which they categorize into three main phases: understanding, planning, and managing. In addition to providing a useful heuristic for analyzing barriers that might be identified, the framework can be used as a comparison for understanding how far along agencies might be in their processes toward full implementation of planned adaptation (see Fig. 1).

Fig. 1. Moser and Ekstrom's phases and stages of the adaptation process. Source: Moser and Ekstrom (2010:22027).

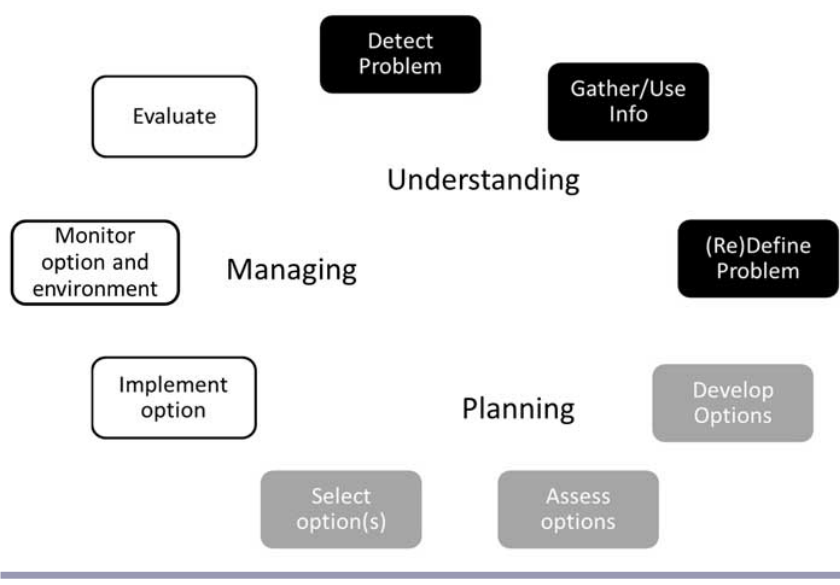

We present the results of a survey of the decision making context and progress on adaptation in four federal public lands agencies across three western U.S. states. The results are presented in three major categories. First, we report on the decision making context for public lands managers in this region, focusing on the challenges they report and their own perceptions about what the consequences of climate change might be for their management area. Second, we discuss the stage of adaptation planning in which agencies seem to be engaged, and what the major perceived barriers to further progress on adaptation might be. We highlight in the findings the differences across agencies because that was the only major predictor of differences in adaptation progress in our data. Third, we discuss the degree to which adaptation planning might be different from existing plans or merely represent relabeled efforts. We conclude with a discussion of our findings in the context of Moser and Ekstrom's framework, to analyze where in the process of adaptation agencies might be, and how barriers to adaptation might be explained across agencies.

\section{METHODS}

To obtain data about individual land manager and agencylevel adaptation barriers and plans, we conducted an online survey similar to prior surveys on adaptation planning (Tribbia and Moser 2008, Theoharides et al. 2009, Amundsen et al. 2010). This survey was sent to approximately 3100 land managers employed by the BLM, the USFS, NPS, and the FWS in Colorado, Utah, and Wyoming. The survey was pretested on a group of qualified respondents to ensure questions were worded clearly and were relevant to the proper audience. Approval was obtained from the University of Colorado Institutional Review Board prior to testing.

Recent research shows that electronically administering surveys decreases the average response time (Sheehan and McMillan 1999) and increases the researchers' ability to track responses (Sheehan 2001). In addition, email surveys have been shown to elicit more candid responses from participants compared with phone surveys (Bachmann et al. 1999), and responses to open-ended questions have been shown to be longer for electronic surveys than for those delivered in other formats (Paolo et al. 2000).

The names and email addresses of land managers were obtained from publicly available phone and email lists on agency web sites. Many studies have emphasized the importance of multiple reminders in increasing response rates (Murphy et al. 1991, Mehta and Sivadas 1995, Taylor and Lynn 1998, Sheehan and Hoy 1999, Sheehan and McMillan 1999, Dillman 2000) so a description of the study including a link to the survey was emailed to the sample of public lands managers five times during four months. We used SurveyMonkey to collect the survey data and to manage our respondent lists, maintaining confidentiality and allowing potential respondents the option to opt out permanently. Qualified participants included directors, planners, engineers, water resources managers, environmental specialists, field managers, staff scientists, and others as deemed appropriate during the survey test. The term "land manager" is thus loosely defined as those both making decisions about public lands as well as those providing advice and information in support of decision making.

The survey was composed of 39 total questions including open-ended, Likert scale, check-all, and forced-choice questions, and was administered from March 2011 to June 2011. A total of 676 respondents began the survey, 511 completed the entire survey, and 14 refused the informed consent and were not allowed to continue. The overall 
response rate was $21.8 \%$, which is what can be expected of an online survey of this size launched after the year 2000 (Sheehan 2001). Because all questions except for the initial informed consent requirement were optional, some questions have more responses than others. We specifically targeted respondents based on their job title, thus our results are not necessarily representative of the views of all agency employees in these states. The 25 survey questions that are relevant to this article are provided in Appendix 1.

Following the collection of survey data, interviews were conducted of a sample of the survey population. We used a purposive sampling technique (Tongco 2007) that targeted a range of respondents with varying degrees of management responsibilities across each of the four agencies. Interviewees included scientists, resource managers, and administrators. A total of 12 interviews were conducted between June and September of 2011 and were recorded with the respondents' consent. Eight of the interviews were conducted in person and four were conducted via telephone. Interviewees were first given a summary of our research goals and a general explanation of how we define adaptation, and were then asked about the main challenges they currently face, where climate change ranks on that list, whether their office is currently engaging in adaptation planning, what the major barriers are to further adaptation, and how influential the public is in their decision making. Other questions were included where relevant. When it was not clear whether responses specifically addressed adaptation or just climate change in general, the interviewer posed a new question to specifically address adaptation. Thus, interviewee responses can be assumed to reflect views on adaptation specifically. Content analysis of the qualitative data from this portion of our work established the recurring themes for each major interview question and provides a better understanding of participants' survey responses.

\section{RESULTS}

\section{Challenges facing land managers}

To gain contextual perspective, we asked respondents to choose from a list of physical/biological challenges and a list of other challenges that were more social or organizational in nature (Appendix 1, questions 1 and 2). We were interested in knowing whether the challenges managers face generally are the same as those they consider to be barriers to adaptation. The most commonly chosen physical or biological challenge overall was species and habitat management $(78 \%)$, and funding was chosen as the most common other challenge $(77 \%)$.

We followed these questions with an open-ended question asking respondents to list the top three management challenges currently facing their office (Appendix 1, question 3). Allowing open-ended responses to this question ensured that the answers accurately reflected the views of the land managers and not just the researchers' assumptions. The most common answers were: lack of funding, species and habitat management, stakeholder conflicts, and personnel constraints. Twenty-four percent of respondents chose lack of funding as their biggest challenge followed by $12 \%$ who chose species and habitat management. Of the 1487 total responses to this question, issues dealing with funding comprised $16 \%$, species and habitat management accounted for $11 \%$, and stakeholder conflicts and personnel constraints accounted for $9 \%$ and $8 \%$, respectively.

To gauge the relative importance of the challenges provided by the respondents, in question 4 we asked them to rate the severity of the top physical, biological, or other management challenge that they listed in the open-ended question. Sixtynine percent of the respondents who answered this question rated the top management challenge in their office as severe or very severe with only one respondent answering that their challenge is not severe at all. The majority of respondents from all agencies reported their most pressing challenge as severe. Thus, the challenges listed by respondents are not trivial and can be assumed to comprise or impact a large part of their work.

Nearly every interviewee included some reference to issues of limited funds and issues dealing with endangered species management when asked about current challenges, and other themes seen in the survey responses were apparent as well. According to one BLM interviewee, stakeholder conflicts are the most pressing challenge for his office. He explained that "the external challenge is just the weight of so many public land users, expecting something from the public lands and the growing participatory nature. A lot of people have opinions about how the land should be managed but they haven't as often taken the time to research our agency and our principal mission which is multiple use." The challenges associated with the multiple use mission of some public lands is echoed by a Forest Service interviewee who explains that, "there's only a small area in which people are requesting to either recreate, to extract oil and gas, and to graze cattle, which makes 'multiple use' a really complex task to complete."

Climate change did not rank very high compared with other challenges. Only $5 \%$ of the responses to our open-ended ranking question included climate change and a mere $3 \%$ listed climate change as the number one challenge currently facing their office. In subsequent interviews, participants shed light on why climate change did not rank near the top of their list of challenges. One interviewee explained that, "Climate change is and has been sort of the elephant in the room as it relates to pretty much any of the activities that we authorize. However, as a principal consideration it doesn't really sit any higher or lower than any of the other mandatory elements that we have to evaluate." Another interviewee expressed his 
Fig. 2. Present or future changes in office management plans in response to climate change as reported by survey respondents.

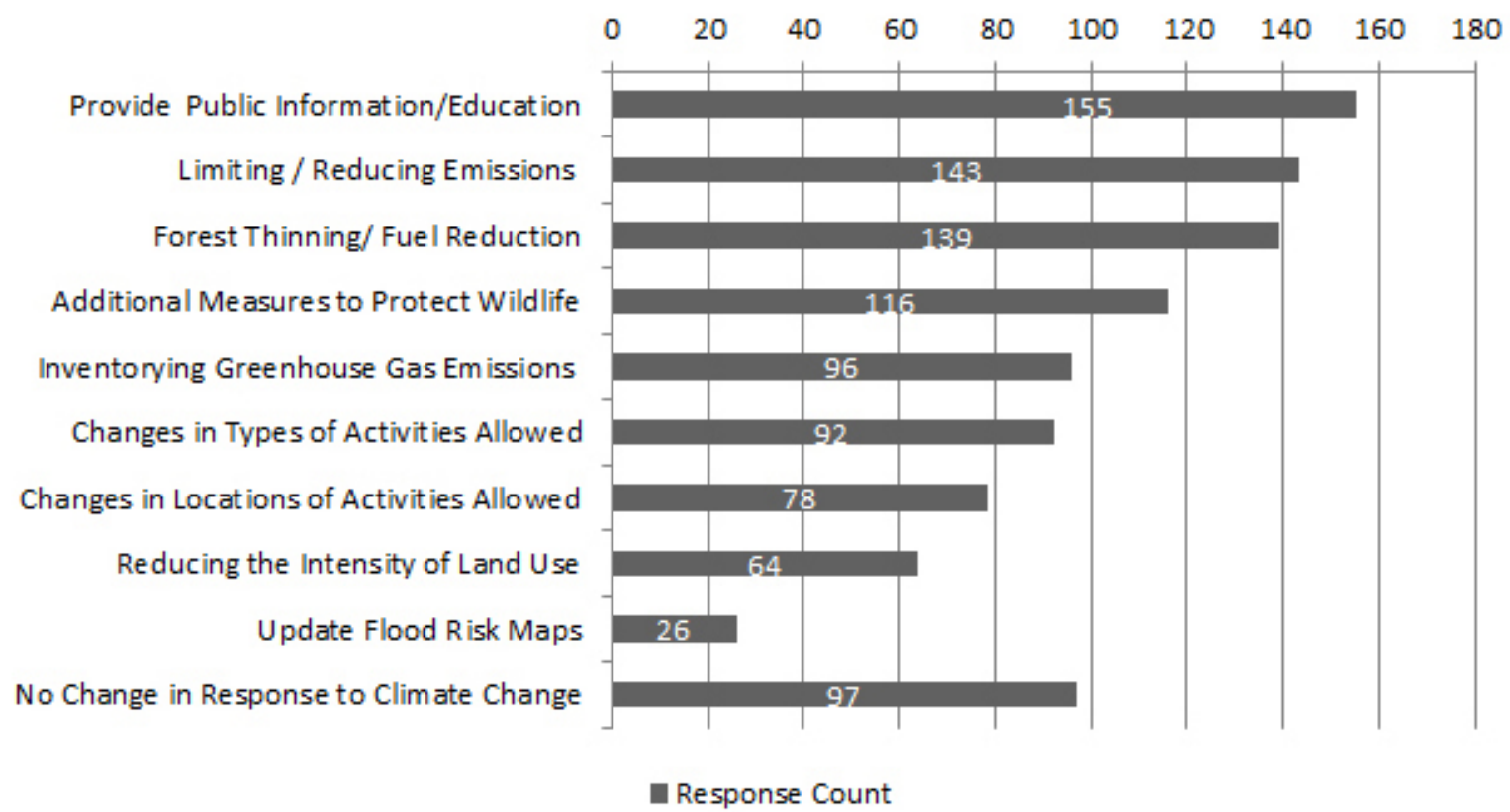

frustration that even though climate change is a high ranking priority for him personally, his capacity to try to engage on and deal with that issue is very limited. However, another interviewee explained that her office is "recognizing that climate change is an issue and that we need to be prepared, but it hasn't been something that has actually come to the point where it would make a significant factor in the decisions that we make."

\section{Consequences of climate change}

To assess perceptions of local vulnerability to climate change, respondents were asked to rate the likelihood of 17 potential impacts of climate change on the land managed by their office (Appendix 1, question 5). The intent of these questions was to understand how managers were viewing climate change in the context of their particular region. Five of the potential consequences that we offered were increased local air temperatures, increased local water temperatures, negative impacts on local wildlife, changes in local runoff timing, and increase in local potential for catastrophic wildfire. These were perceived as at least moderately possible and all other potential consequences were believed to have a less than moderate possibility of happening as a result of climate change. The four potential consequences that were considered to be the least likely were those that assume positive impacts from climate change, i.e., positive impacts on nearby communities, positive impacts on local recreation, positive impacts on local ecosystems, and less local flooding.
We also asked respondents what, if any, changes their office has already made or will make in response to climate change (Appendix 1, question 6). The four most common responses were provision of additional information/educational materials to the public, limiting or reducing emissions, forest thinning/fuel reduction, and additional measures to protect wildlife (Fig. 2).

\section{Adaptation planning and barriers to planning}

One of the main goals of our research was to establish whether federal land agencies were actually engaged in activities related to climate change adaptation on the ground. Respondents were first asked whether or not their office has developed strategies or plans to deal with the potential impacts from climate change (Appendix 1, question 7). The answers to this question varied dramatically both between and within agencies. Overall, $47 \%$ of the respondents who answered this question report that their offices are not currently planning for adaptation to climate change, $24 \%$ answered that their offices are currently developing adaptation plans, and an additional $5 \%$ claim that adaptation plans are currently being implemented or carried out (Fig. 3). The remaining 24\% answered that they did not know. These responses are consistent with prior literature on the topic that suggests few adaptation efforts have reached the implementation stage (Berkhout et al. 2006, Adger et al. 2007, Dovers 2009, GAO 2009, Berrang-Ford et al. 2011). 
Fig. 3. Reported adaptation planning.

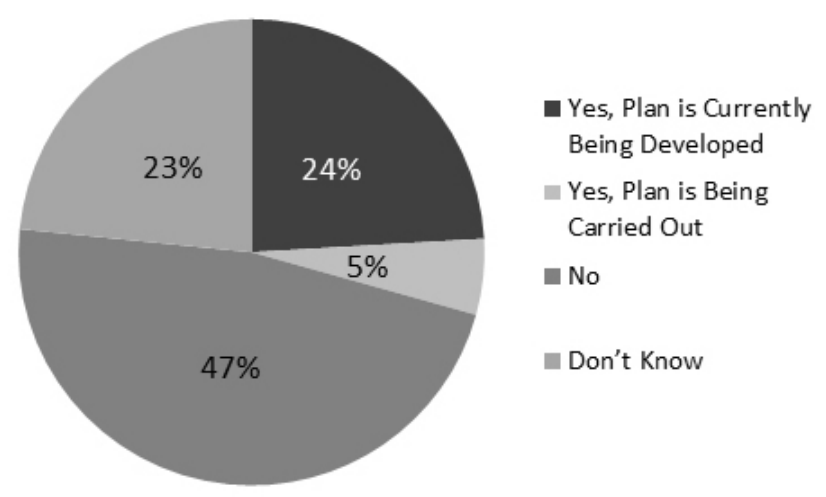

Responses to this question varied across agencies (Pearson $\mathrm{X}^{2}$ $=81.43, \mathrm{p}=0.00)$. The majority $(60 \%)$ of BLM employees said they were not developing adaptation plans, whereas 50\% of USFS respondents said that they were either developing adaptation plans or such plans were already being carried out (Fig. 4). Seventy-eight percent of NPS respondents reported that their office was not developing adaptation plans or that they did not know. Responses from FWS respondents were split with $51 \%$ reporting that their office was planning or enacting adaptation strategies, $43 \%$ reporting no planning, and $5 \%$ reporting that they did not know. FWS respondents reported the highest level of implementation with $24 \%$ reporting that plans were currently being carried out.

Fig. 4. Reported adaptation planning by agency.

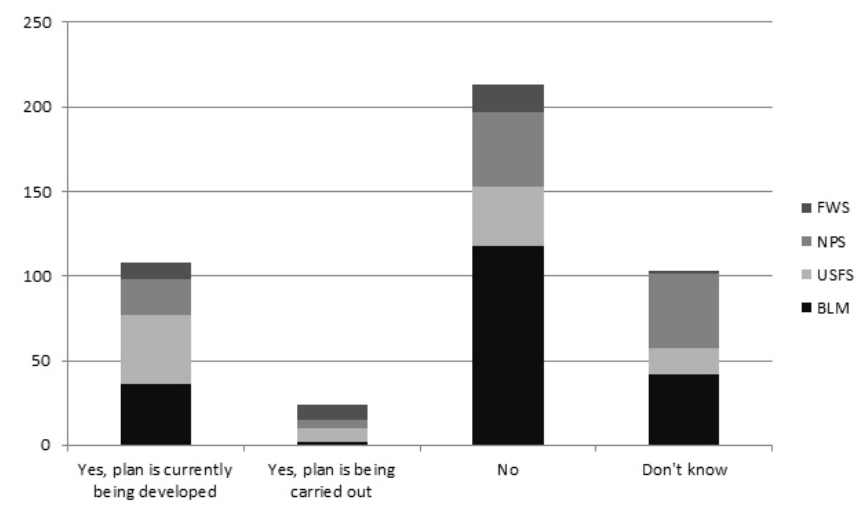

We conducted ordered logistic regression analysis using demographic data from our survey as well as other potentially influential variables to analyze their potential effect on the reported status of adaptation planning. In addition to demographic questions (Appendix 1, questions 14 to 25), we asked respondents questions aimed at establishing their attitudes and beliefs about climate change (Appendix 1, questions 8 and 9). We used this information to assess whether these characteristics were correlated with responses about adaptation planning. The responses to the attitudinal questions revealed that $73 \%$ of respondents believed that climate change is real and already happening and $65 \%$ believed that climate change is a serious or very serious problem. We then asked respondents to report how well-informed they were about climate change (Appendix 1, question 10) and 86\% claimed to be either moderately or well-informed about these topics. We conducted a reliability analysis for the questions about beliefs and attitudes toward climate change and computed an index variable to establish a composite attitudinal variable. This new index variable was then used in our further analysis. $($ Chronbach's alpha $=0.73)$.

The results of the ordered logistic regression show that the agency in which the respondent works is the only statistically significant predictor of reported adaptation planning ( $\mathrm{p}=$ 0.004)(Table 1). None of the other predictors, i.e., education, age, gender, years with the agency, beliefs, and attitudes about climate change, or whether the respondent was a scientist, had a significant relationship with responses about adaptation planning.

Table 1. Ordered logistical regression analysis of adaptation planning.

\begin{tabular}{lcccc}
\hline \hline Predictor & $\beta$ & $S E$ & $z$ & $p>|z|$ \\
\hline CC Belief Index & 0.164 & 0.157 & 1.04 & 0.298 \\
Years with & 0.002 & 0.016 & 0.14 & 0.887 \\
agency & & & & \\
Education & 0.297 & 0.235 & 1.26 & 0.206 \\
Gender & 0.409 & 0.268 & 1.53 & 0.127 \\
Age & 0.011 & 0.017 & 0.70 & 0.485 \\
Scientist & -0.101 & 0.342 & -0.29 & 0.769 \\
BLM & & & & \\
USFS & 1.361 & 0.343 & 3.97 & 0.000 \\
NPS & 0.451 & 0.353 & 1.28 & 0.202 \\
FWS & 1.428 & 0.421 & 3.39 & 0.001 \\
Cut 1 & & & \\
Cut 2 & 5.977 & & & \\
pseudo ${ }^{2}=$ 0.07, pseudo $R=0.26$ & & \\
BLM = Bureau of Land Management & & \\
USFS = U.S. Forest Service & & \\
NPS = National Park Service & & \\
FWS = U.S. Fish and Wildlife Service &
\end{tabular}

To understand why actors on the ground think that adaptation planning is not taking place more widely we asked respondents to rank the top three most important factors preventing them from planning for adaptation (Appendix 1, question 11). Overall, lack of information at relevant scales and budget constraints were the two most common answers as well as the two options with the highest rankings (Fig. 5). Two other information-based barriers and lack of specific agency direction round out the top five. 
Fig. 5. Ranking of barriers to adaptation planning by total responses. Survey respondents were asked to rank their top three choices with "1" being the biggest barrier to adaptation.

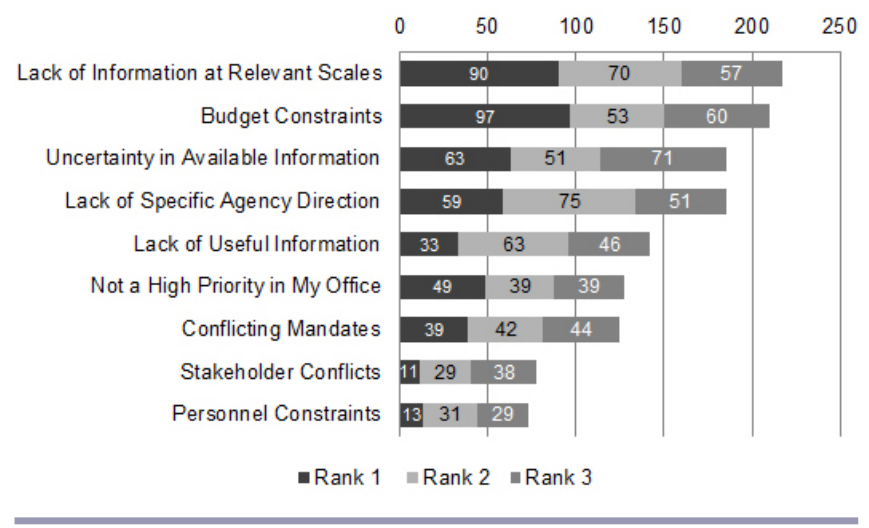

We then asked respondents a separate question to understand more broadly how they perceived hurdles in the adaptation process (Appendix 1, question 12). We consider these responses as characterizing the types of problems respondents associate with the implementation of adaptation activities, as opposed to the planning process itself. Respondents were allowed to indicate choices as either a big hurdle, small hurdle, not a hurdle, or to report that they did not know. Once again, budget constraint was seen as the biggest hurdle to adaptation, followed by lack of perceived importance to public, lack of public awareness, or demand to take action, and insufficient staff resources to analyze and assess relevant information (Fig. 6 ). The options that ranked the lowest as potential hurdles were not a high priority in my office, and legal pressures to maintain status quo.

Because responses dealing with public sentiment ranked high on the list of hurdles to implementation of adaptation plans, we asked interviewees the extent to which public opinion affects decision making. Responses from interviewees resoundingly highlighted the importance of working with and understanding the different stakeholders in their region. Public involvement in planning takes place during the public comment period required by the National Environmental Policy Act (NEPA) process, but interviewees were split about the extent to which this input actually affects on the ground decisions. Concerns and input from the public are considered, but decision making on public lands is not a voting process. Another complicating factor cited multiple times was a lack of consensus in public opinion. Public input does appear to play a more important role for agencies with multiple use mandates; however, even interviewees from the FWS explained that though the ESA does not require public involvement like NEPA does, the agency still makes an effort to work with stakeholders affected by their decisions. Interviewees also felt that public resistance to climate change measures was likely based more on lack of information and education than on deeply held values and beliefs. The overall sense was that good science and scale relevant information would depoliticize adaptation actions on a local scale because the public generally desires sound planning that maintains the health and viability of the land. A minority of interviewees did express concern that even with sound, relevant science some segments of the public would remain unwilling to accept any changes to management based on climate change. Another challenge associated with public sentiment mentioned by interviewees was public "willingness to accept certain impacts in exchange for certain benefits." Conflicting values of local stakeholders, often associated with the multiple use missions of some public lands agencies, causes tension when dealing with management changes related to climate change or otherwise. As expected, respondents from the four agencies differed in both their ranking of the barriers to adaption planning (Fig. 7) and in their responses to the question about hurdles to implementation of adaptation plans.

\section{Perceptions at the Bureau of Land Management}

The most commonly cited barriers to adaptation planning (question 11) for respondents from the BLM were lack of specific agency direction, lack of information at relevant scales, and budget constraints. These three identified barriers are consistent with the second or "planning phase" of the adaptation framework outlined by Moser and Ekstrom (see Fig. 1). The first stage of this phase entails developing adaptation options, includes identification of agreed upon goals, and relies heavily on leadership. The biggest hurdles to implementation (question 12) reported by BLM respondents were lack of perceived importance to public, lack of public awareness, or demand to take action, budget constraints, and insufficient staff resources to analyze and assess relevant information. Responses from BLM interviewees about adaptation planning barriers and implementation hurdles are consistent with these results. One BLM employee explained that his office is still trying to figure out how to model and understand the impacts of climate change in their area so they have yet to even discuss adaptation strategies. The main barriers to additional progress from this employee's perspective are resource based. "We don't have the capacity to fund adaptation projects, or to hire the staff to participate in the projects. We don't have the capacity or staff expertise to synthesize the information that may or may not be available in the first place." Another BLM employee explained that from his perspective Executive Order 13514 was quite clear and that additional direction was not the primary reason the BLM is not further along in planning for adaptation. According to this employee the multiple use mission of the agency and their reactive management process makes incorporating climate change information into their current decision making 
Fig. 6. Hurdles to adaptation implementation by big hurdle percent. Respondents had the option of choosing big hurdle, small hurdle, or not a hurdle.

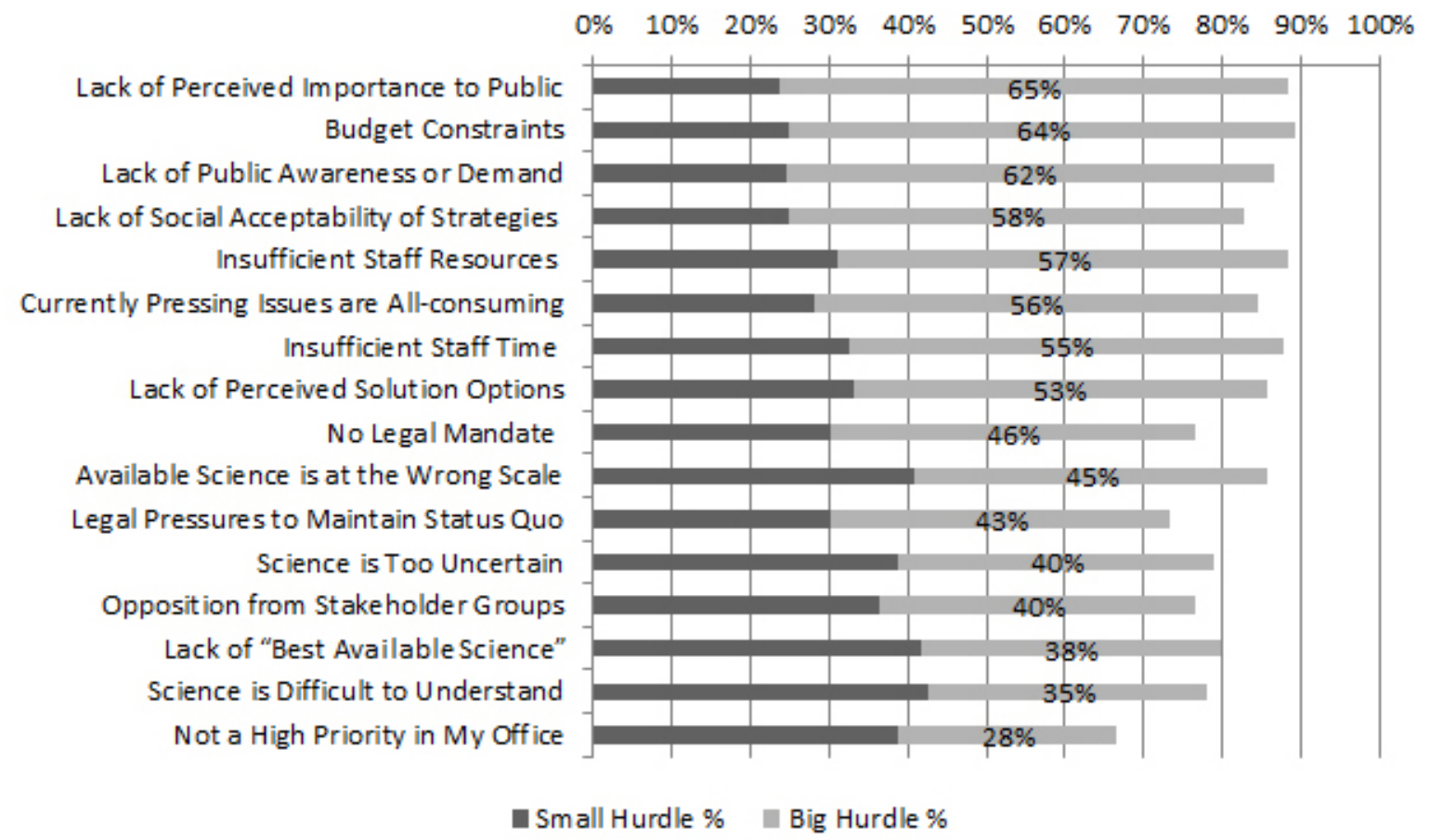

difficult. Another BLM interviewee explained that she would be hesitant to include climate change planning into her management practices without more specific information. Finally, a BLM interviewee explains that consequences of climate change are not as acute in his region "so the adaptive strategies seem a bit more of a stretch. They don't seem as necessary, and yet they do seem costly."

\section{Perceptions at the U.S. Forest Service}

Responses from the USFS looked similar to those from our overall sample with lack of information at relevant scales chosen as the largest barrier to adaptation planning followed by budget constraints, and uncertainty in available information. Information concerns, which accounted for $43 \%$ of the USFS responses to this question, are consistent with the second stage of the planning phase of the Moser and Ekstrom framework (see Fig. 1). This stage titled "assessing options" relies heavily on the availability of relevant and usable information. The biggest hurdles to implementation reported by USFS respondents were budget constraints, lack of social acceptability of strategies that take global warming into account, lack of perceived importance to public, currently pressing issues are all consuming, and the science is too uncertain. Comments from USFS interviewees are consistent with survey results and provide insight into the responses to these questions. One USFS employee explained that when it comes to using information, especially for adaptation planning, the problem is that most science is written for scientists and although he admits that some academic discussion can further our understanding, this type of information is not very useful to land managers. Other employees admit that even the science that is written to be practically useful is often left unused because of a lack of time for staff to read and synthesize it, a point that echoes the recurring concern over resources. Another USFS employee explained that, from his perspective, barriers we have discussed such as information, funding, and direction can be overcome, but that integrating climate change into management decisions will continue to be a slow process simply because of the size of the Forest Service and the scope of their responsibilities.

\section{Perceptions at the National Park Service}

Budget constraint was chosen as the largest barrier to adaptation planning for NPS respondents. The other common responses from NPS respondents were lack of information at relevant scales, uncertainty in available information, and lack of specific agency direction. Budget constraint is one of the major cross-cutting issues identified by Moser and Ekstrom, thus interpretation of this result can be difficult. However, the other common barriers reported by NPS respondents and the overwhelming percentage $(78 \%)$ of NPS respondents that 
Fig. 7. Barriers to adaptation planning by agency. Bars represent the percentage of respondents from each agency who ranked the option as one of their top three choices.

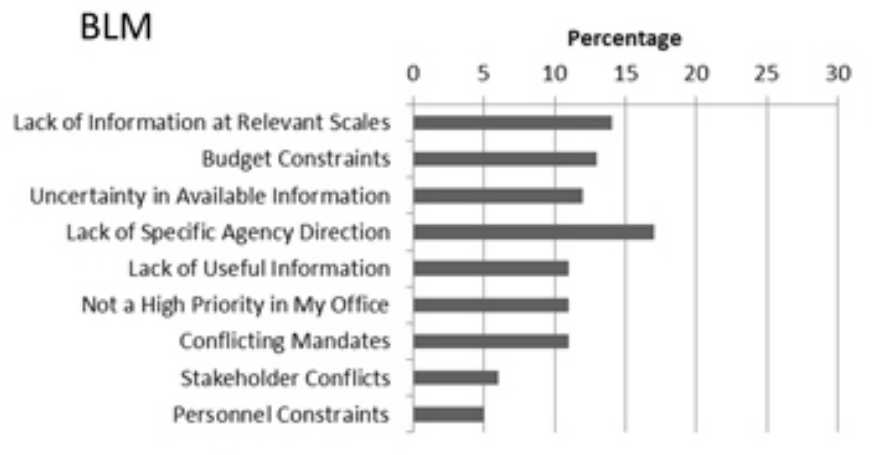

. $\%$ of respondents who ranked as either 1,2 or 3

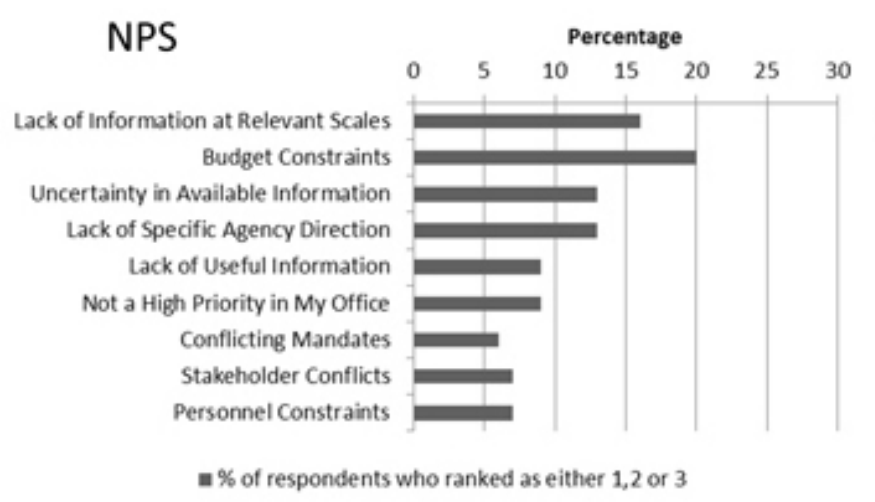

FWS

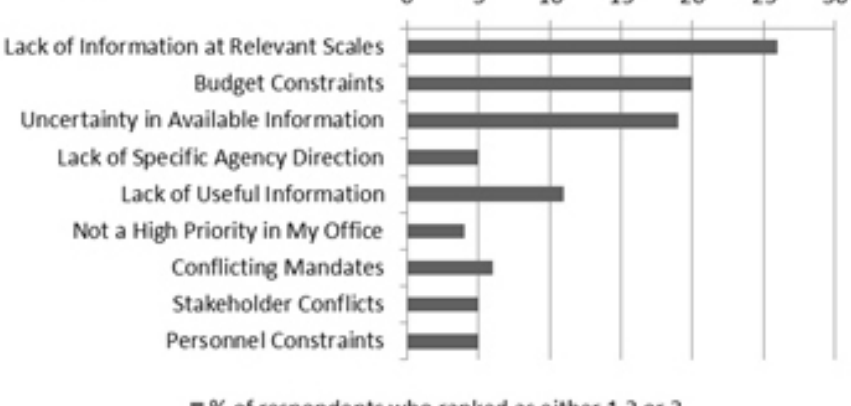

USFS

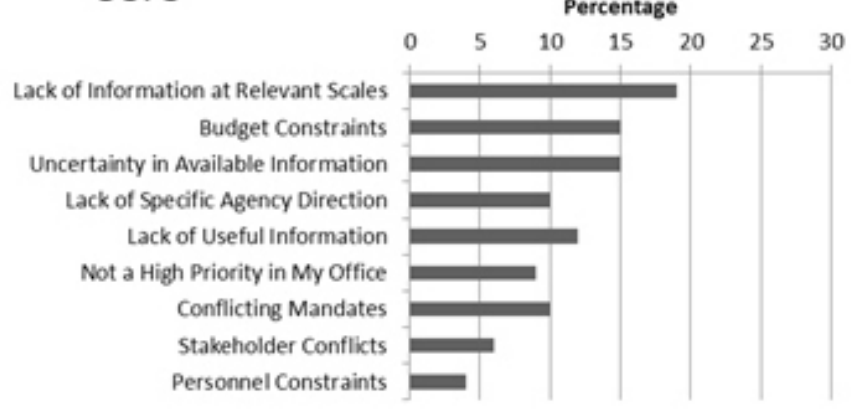

- \% of respondents who ranked as either 1,2 or 3 report either no current adaptation planning or that they do not know whether adaptation planning is taking place are consistent with the late stages of the understanding phase of the adaptation framework (see Fig. 1). The biggest hurdles to implementation reported by NPS respondents were budget constraints, lack of perceived importance to public, and lack of public awareness or demand to take action. Interview responses from NPS employees consistently echoed the same themes. A NPS interviewee shed some light on the strength of the Department of the Interior's influence over decision making on public lands. He explained that adaptation planning takes place, but it is often adaptation in response to changes in rules and administration not to climate. Decision making on NPS lands, in this employee's experience, is not always based on the science they have collected but rather on who is giving directions. Other NPS interviewees said that only beginning in 2009 have they had any direction from Washington or the regional level on climate change related measures, thus their work is still in the early stages. Interviewees also explained that the direction they have been given is not specific enough to make the decision making and planning process efficient. Generally, NPS interviewees report uncertainty in the available information and agency priorities as the primary barriers to adaptation. One interviewee explained that compared to the multiple use mandates of some of the other public lands agencies, the NPS focus on visitor experience could be one of the greatest challenges for climate change adaptation planning. Managing NPS land as a national treasure for future generations becomes increasingly complicated if climate change makes maintaining the original characteristics unsustainable.

\section{Perceptions at the U.S. Fish and Wildlife Service}

Lack of information at relevant scales was the most common barrier to adaptation planning reported by FWS respondents followed by budget constraints and uncertainty in available information. These responses are consistent with the second stage of the planning phase of the adaptation process outlined by Moser and Ekstrom (see Fig. 1). This is the same stage that was identified for the USFS, which entails assessing adaptation options and relies heavily on having usable, relevant information. The biggest hurdles to implementation reported by FWS respondents were lack of perceived importance to public, lack of public awareness or demand to take action, and currently pressing issues are all consuming. FWS interviewees explained that climate change is taken into 
Table 2. Degree to which climate change adaptation plans differ from prior management plans.

\begin{tabular}{|c|c|c|c|c|c|c|c|}
\hline & \multicolumn{4}{|c|}{ Agency } & \multirow[b]{2}{*}{$X^{2}$} & \multirow[b]{2}{*}{$p$} & \multirow[b]{2}{*}{ Cramer's $V$} \\
\hline & BLM & USFS & NPS & FWS & & & \\
\hline Don't know & $49 \%$ & $33 \%$ & $43 \%$ & $56 \%$ & 33.07 & $<0.001$ & 0.16 \\
\hline No change & $14 \%$ & $11 \%$ & $7 \%$ & $0 \%$ & & & \\
\hline Differ slightly & $29 \%$ & $39 \%$ & $34 \%$ & $14 \%$ & & & \\
\hline Differ significantly & $7 \%$ & $17 \%$ & $16 \%$ & $31 \%$ & & & \\
\hline
\end{tabular}

$\mathrm{BLM}=$ Bureau of Land Management

USFS $=$ U.S. Forest Service

NPS = National Park Service

FWS $=$ U.S. Fish and Wildlife Service

account in both endangered species listing decisions as well as analysis of long-term projects. One interviewee did point out that although the ESA can take climate change into account as a threat to a species, it is probably not equipped to deal with situations in which climate change is the primary factor threatening a species. Another FWS interviewee explained that depending on the situation and the species, additional information would be useful, but typically does not come in the most relevant format and thus does not always prove to be useful. This interviewee suggested that a glut of generally relevant information can sometimes be a burden because it can be difficult to synthesize and represent fairly. Overall, FWS interviewees suggest that additional information would be welcomed but may not be the deciding factor in increasing adaptation planning.

\section{How different are adaptation plans from other types of plans?}

Some actions taken in response to predicted changes in climate are similar to, or the same as, plans that are already in place for alternative reasons. For example, forest thinning is sometimes considered adaptation to climate change but often takes place for alternative reasons as well (Spittlehouse and Stewart 2003, D'Amato et al. 2011). Relabeling existing activities as climate change adaptation strategies is a potential response to planning mandates as opposed to having to develop new adaptation specific strategies. To assess whether adaptation planning consists of incorporating new ideas and strategies specifically aimed at addressing consequences of climate change, or alternatively that current plans are merely being relabeled or amended, we asked respondents about the degree to which climate change adaptation plans will differ from prior management plans (question 13). Forty-five percent of the respondents reported that they do not know how plans will change, $10 \%$ reported that there will be no change in plans, $31 \%$ reported that there will be slight changes, and $13 \%$ expected adaptation plans to differ significantly from prior management plans. It is impossible to tell whether responses of "no change" reflected a lack of need or ability to change plans in response to climate change or whether it means that current plans were relabeled as adaptation activities.

Across the agencies the largest percentage of respondents from each agency report that they do not know to what extent climate change adaptation plans will differ from prior management plans (Table 2). However, the distribution of responses within the agencies differ significantly (Pearson $\mathrm{X}^{2}=33.07 \mathrm{Pr}=0.00$ ). Fifty percent of BLM respondents reported that they do not know the extent to which plans will differ. In contrast, $56 \%$ of USFS respondents reported that plans will differ either slightly or significantly, as did 50\% of NPS respondents. Fiftysix percent of FWS respondents did not know whether plans will differ at all whereas the remaining $44 \%$ reported that plans will differ either slightly or significantly.

Responses from interviewees from all agencies reflect similar understanding of changes in planning and shed some light on the practical side of adaptation implementation. One interviewee explained that, "in name there really isn't anything termed adaptation, in practice there are some things that fit neatly into a category of adaptation planning." The idea that there may be adaptation-type activities going on but that they are not necessarily labeled adaptation is echoed by an interviewee who, after describing some activities on the lands his office manages that could be considered adaptation but are not labeled as such, explained "it's kind of the normal way of doing business."

\section{DISCUSSION}

The main goals of our study were to assess the current state of adaptation planning and implementation on public lands in Colorado, Utah, and Wyoming. The guidance to consider climate change in federal land management has been present for about a decade, to varying degrees, but it has been unclear how this mandate has affected on the ground practices. We sought to both characterize the extent of adaptation planning on the ground, and to determine what barriers exist to further adaptation planning and action. 
Overall, we found that about a quarter of agency managers were aware of planning for adaptation to climate change in their offices. These agency managers are planning for climate change even though it ranks very low on their overall list of top-ranked challenges. More than three-quarters of the managers we surveyed said they believed that climate change is real, and that it is an urgent problem. This contrasts with surveys of the general public, only $39 \%$ of whom are classified by Leiserowitz and others in their recent Global Warming's SixAmericas study as either alarmed or concerned about global warming (Leiserowitz et al. 2011). This perceived urgency may partially explain why planning is underway in some offices even though it is seen as the top management challenge for only a very small percentage of our survey population. This finding also suggests that climate change will likely be handled not as a single issue, but as layered on top of a suite of other more pressing issues that managers see as their top challenges (e.g., Failey and Dilling 2010, Ellenwood et al. 2012; Dilling and Failey, in press).

On the other hand, actions to implement adaptation plans were not common with only $5 \%$ of agency managers across the board stating that adaptation planning was being carried out. This suggests that the agency offices on the ground might fall more in the first and second stages of the adaptation process as suggested by Moser and Ekstrom (2010), rather than the third stage, which focuses on managing adaptation activities (see Fig. 1). This finding is supported by the barriers and hurdles suggested by the respondents that mostly correspond to the second or planning phase. The most common barriers to adaption planning reported by our sample as a whole were lack of information at relevant scales, budget constraints, lack of specific agency direction, and lack of useful information. Among these answers, information-related barriers are commonly associated with the second stage of the planning phase, which deals with assessing adaptation options (see Fig. 1). Lack of agency direction is also a barrier associated with the planning phase of the adaptation process, more specifically with the developing options stage that relies heavily on leadership. During this phase, leadership and information are vital components facilitating development and assessment of potential adaptation options. Lack of necessary information and leadership at this point in the process would explain responses of both no planning and some planning without implementation (Moser and Ekstrom 2010).

These findings provide confirming evidence that technical expertise and new knowledge can be an important component of successful policy implementation, a factor that is often overlooked by studies of policy implementation that assume that "implementing actors know what to do in order to operationalize policies" (Schofield 2004:290). Schofield (2004) emphasizes the importance of gaining new expertise and learning over time for new policy mandates to be successfully implemented. Moreover, agencies are mandated to consider the "best available science" by law in their decision making (Clark 2009), which suggests there is an opportunity for providing more relevant, usable science for adaptation decision making on public lands.

We did see statistically different results in climate change adaptation among the four agencies surveyed. Even though in the first phase of the adaptation process the perspective of the actors involved is highly influential in detecting the problem, gathering and using information, and redefining the problem, surprisingly, individual beliefs about climate change did not correlate with where agency offices were in the adaptation process. The only statistically robust predictor of being farther along in the adaptation process was the agency identity itself. As discussed by Reiners (2012) for the area of fire management in public land agencies, the role of the institutional context and interactions among institutions may be a strong determining factor in the degree of success in implementing a change in policy direction on the ground. Moreover, the missions of each agency can differ in the degree to which they are multiple-use focused (BLM and FS) or dominant-use focused, i.e., focused on one main mission (NPS and FWS). These institutional contexts also greatly affect how an agency can interpret a given new policy paradigm such as incorporating a more flexible fire management regime (Wise and Freitag 2002) and potentially climate change adaptation. We therefore present our analysis of the barriers perceived by participants broken out by specific agencies.

\section{Adaptation progress for the Bureau of Land Management}

As detailed in our results section, the most commonly cited barriers to adaptation planning for respondents from the BLM were lack of specific agency direction, lack of information at relevant scales, and budget constraints. These three identified barriers are consistent with the second or planning phase of the adaptation framework. The first stage of this phase entails developing adaptation options, includes identification of agreed upon goals, and relies heavily on leadership (Moser and Ekstrom 2010). BLM employees cited lack of direction as the most common barrier to adaptation planning, which is consistent with this stage of the process, though one interviewee felt there had been sufficient direction related to Executive Order 13514. Responses from BLM interviewees about adaptation barriers are also consistent with those identified by Moser and Ekstrom for the late stages of the understanding phase or the first stage of the planning phase. Funding is a crosscutting theme, which could be associated with all three phases of the process, but in this case because potential adaptation strategies are often mentioned as the costly measure, this result remains consistent with the barriers recognized in the planning phase as well.

\section{Adaptation progress for the U.S. Forest Service}

Information concerns accounted for $43 \%$ of the USFS responses to the barriers to planning question and are 
consistent with the second stage of the planning phase of the Moser and Ekstrom framework. The stage within planning of assessing options relies heavily on the availability of relevant and usable information. Information concerns coupled with more general resource constraints may explain why $41 \%$ of USFS respondents reported that adaptation planning was already taking place, but only $8 \%$ reported that adaptation plans were already being carried out. Without sufficient information or resources, the planning process can stall before the management or implementation phase. Comments from USFS interviewees are consistent with survey results and with the barriers associated with the planning phase of the adaptation process.

\section{Adaptation progress for the National Park Service}

Budget constraints were identified by NPS respondents as the largest barrier to adaptation planning. This result can be difficult to interpret for its correspondence to any one particular stage of the framework because this is one of the major crosscutting issues identified by Moser and Ekstrom. However, the other common barriers reported by NPS respondents, "lack of information at relevant scales," "uncertainty in available information," and "lack of specific agency direction," and the overwhelming percent of NPS respondents who reported either no current adaptation planning or that they did not know whether adaptation planning was taking place (78\%) give an overall result that is consistent with the late stages of the understanding phase. Interview responses from NPS employees, many of which mentioned prioritization of visitor experience as an obstacle to adaptation, are consistent with this result.

\section{Adaptation progress for the U.S. Fish and Wildlife Service}

Lack of information at relevant scales, budget constraints, and uncertainty in available information were the most commonly reported barriers to adaptation by FWS respondents. These responses are consistent with the second stage of the planning phase of the adaptation process outlined by Moser and Ekstrom. This is the same stage that was identified for the USFS, which entails assessing adaptation options and relies heavily on having usable, relevant information. Responses to our survey revealed that the FWS had the highest reported level of adaptation implementation of the four agencies surveyed. Twenty-four percent of FWS respondents reported that adaptation plans were already being carried out, compared with only $8 \%$ from the USFS, $4 \%$ from the NPS, and $1 \%$ from the BLM. Because more than half of the FWS respondents reported that adaptation plans were either being developed or were being carried out, it appears that a lack of information or other resources has not prevented the FWS from making some progress on adaptation. Thus, the aggregate FWS data may actually be more consistent with the later stages of the planning phase and the early stages of the managing phase. Overall, FWS interviewees suggest that though additional information would be welcomed, the acute effects of climate change that impact individual species necessitate a more proactive approach than that currently adopted by other agencies. Adaptation decisions could have a huge impact on the survival of threatened and endangered species, and thus FWS employees working under the ESA may be more likely to move forward with planning in spite of uncertainty in information, given their clear legal mandate. This result reinforces the findings of previous work in this area that the ESA can provide a strong impetus for action (Cashore and Howlett 2007).

\section{CONCLUSION}

Our results suggest that adaptation planning by public lands agencies in Colorado, Utah, and Wyoming is occurring but that implementation of these plans remains relatively rare. Individual beliefs and attitudes about climate change do not appear to influence responses about adaptation planning in our study. However, the agency for which a respondent works is a statistically significant predictor of respondents' assessments of current adaptation planning. The FWS may in fact be the farthest along in the process. We hypothesize that this could be due to a more targeted mission of this agency that allows for more immediate inclusion of climate change effects into the planning process. Differences between the responses from the BLM and USFS were apparent despite their similar multiple use mandates. Documented differences between these two agencies in structure and culture, funding, use of science, collaboration with stakeholders, and political power has sometimes led to dissimilar management practices and outcomes and are likely responsible for some of the differences in adaptation response (Clarke and McCool 1996, Koontz and Bodine 2008). A 2008 study comparing BLM and USFS implementation of ecosystem-management components found that internal resistance to change, innovation, experimentation, and risk taking could be partially responsible for land agency hesitation in implementing new strategies (Koontz and Bodine 2008). Though responses from interviewees in our own study did not necessarily echo these same themes, it is possible that some of the same cultural legacies prevent federal land agencies from being more proactive on adaptation to climate change. Because adaptation planning remains a relatively new focus for public lands it is not currently possible to assess the long-term effectiveness of mandates to consider climate change in public land management. Larger scale changes in management practice and increased implementation of adaptation measures could allow for future evaluation of the effectiveness of the policy.

Prior work suggests that more robust leadership in natural resource management can facilitate improved transitioning to new management styles (Danter et al. 2000, Koontz and Bodine 2008). Danter and others (2000) suggest that successful implementation of ecosystem management in natural resources requires more leadership-oriented agency governance than was required under prior management 
models. The long-term goals of ecosystem management are similar in scope to those of climate change adaptation efforts, and thus the same type of leadership changes may help to facilitate improved adaptation implementation.

The barriers identified in our research are consistent with those found by the GAO in 2009. Understanding where each of our federal land agencies currently are in the adaptation process can allow measures to be initiated to overcome the common challenges. Because many of the responses to our questions highlighted problems related to information, further research should address the specific issues related to information use and demand in this area. Science that is usable for decision making can be produced effectively when researchers work with users to create practically useful information (Dilling and Lemos 2011). Coproduction of science for use in adaptation on public lands could help to bridge the gap between information that is available and information that is usable. Reconciling the differences in the supply of and demand for science could lead to improvements in this area if applied in the context of public lands (Sarewitz and Pielke 2007).

Some interview responses suggest that some adaptation activities are management actions that have existed for some time, but are now being labeled as climate change adaptation to satisfy new mandates. Though this strategy may be the path of least resistance, it is not obvious that these types of actions comprehensively address the range of vulnerabilities to climate change. This type of planning, although practically useful in the short term, should not necessarily be considered a long term substitute to thorough adaptation planning. Additional research is necessary to establish the extent to which existing management actions are compatible with or even effective as climate change adaptation activities on public lands. Finally, lack of funding and budget constraints were recurring themes both as overall challenges and barriers to planning and implementation. Additional understanding about the allocation of financial resources of the different agencies, both for adaptation and otherwise, are beyond the scope of this paper, but could provide details about where in the process additional funding would be most effective.

Public sentiment was one of the major hurdles to implementation reported by our respondents and interviewees. Many of the interviewees suggested that improved education and information for stakeholders would be useful in overcoming this obstacle. On the other hand, our survey respondents cited provision of additional information/ educational materials to the public as the most common action currently taking place in response to climate change. Furthermore, the beliefs held by land managers in our study that public attitudes toward climate change are more dependent on access to information than deeply held values is not consistent with some of the literature (e.g., Leiserowitz
2006). This begs the question as to whether public education is indeed the missing component, or whether there may be other more important obstacles to effective adaptation.

Responses to this article can be read online at: http://www.ecologyandsociety.org/issues/responses. $\mathrm{php} / 5187$

\section{Acknowledgments:}

We thank the hundreds of federal public lands managers who took the time to answer our survey and contribute their knowledge to this study. We also thank our interviewees whose insights provided depth and clarity to our study. We also thank the anonymous reviewers for providing helpful comments that greatly improved this manuscript. We gratefully acknowledge support from the National Science Foundation under NSF Grant No. 0345604 for the Science Policy Assessment and Research on Climate (SPARC) project, as well as funding from the NOAA Climate Program Office through the Western Water Assessment RISA at CIRES, University of Colorado-Boulder. We also gratefully acknowledge CIRES Graduate Research Fellowship support for Kelli Archie. Any opinions, findings, and conclusions or recommendations expressed in this material are those of the authors and do not necessarily reflect the views of the National Science Foundation, the National Oceanic and Atmospheric Administration, or the Cooperative Institute for Research in Environmental Sciences.

\section{LITERATURE CITED}

Adger, W. N., S. Agrawala, M. M. Q. Mirza, K. O'Brien, J. Pulhin, R. Pulwarty, B. Smit, and K. Takahashi. 2007. Assessment of adaptation practices, options, constraints and capacity. Pages 717-743 in M. L. Parry, O. F. Canziani, J. P. Palutikof, P. J. van der Linden, and C. E. Hanson, editors. Climate change 2007: impacts, adaptation and vulnerability. Contribution of Working Group II to the Fourth Assessment Report of the Intergovernmental Panel on Climate Change. Cambridge University Press, Cambridge, UK.

Amundsen, H., F. Berglund, and H. Westskog. 2010. Overcoming barriers to climate change adaptation: a question of multilevel governance? Environment and Planning $C$ : Government and Policy 28:276-289. http://dx.doi.org/10.1068/ c0941

Auld, G., L. H. Gulbrandsen, and C. L. McDermott. 2008. Certification schemes and the impacts on forests and forestry. Annual Review of Environment and Resources 33(1):187-211. http://dx.doi.org/10.1146/annurev.environ.33.013007.103754 
Bachmann, D., J. Elfrink, and G. Vazzana. 1999. E-mail and snail mail face off in rematch. Marketing Research 11 (4):11-15.

Berkhout, F., J. Hertin, and D. M. Gann. 2006. Learning to adapt: organisational adaptation to climate change impacts. Climatic Change 78:135-156. http://dx.doi.org/10.1007/ s10584-006-9089-3

Berrang-Ford, L., J. D. Ford, and J. Paterson. 2011. Are we adapting to climate change? Global Environmental Change 21:25-33. http://dx.doi.org/10.1016/j.gloenvcha.2010.09.012

Bureau of Land Management (BLM). 2010. Climate change: BLM's response. Bureau of Land Management, Washington D.C., USA. [online] URL: http://www.blm.gov/wo/st/en/ prog/more/climatechange.html

Calkin, D. C., M. A. Finney, A. A. Ager, M. P. Thompson, and K. M. Gebert. 2011. Progress towards and barriers to implementation of a risk framework for US federal wildland fire policy and decision making. Forest Policy and Economics 13(5):378-389. http://dx.doi.org/10.1016/j.forpol.2011.02.007

Cashore, B., and M. Howlett. 2007. Punctuating which equilibrium? Understanding thermostatic policy dynamics in Pacific Northwest forestry. American Journal of Political Science 51(3):532-551. http://dx.doi.org/10.1111/

j.1540-5907.2007.00266.x

Clarke, J. N., and D. C. McCool. 1996. Staking out the terrain: power and performance among natural resource agencies. SUNY Press, Albany, New York, USA.

Clark, S. A. 2009. Taking a hard look at agency science: can the courts ever succeed? Ecology Law Quarterly 36:317-355.

Climate Change Science Program (CCSP). 2008. Preliminary review of adaptation options for climate sensitive ecosystems and resources (SAP 4.4). U.S. Environmental Protection Agency, Washington, D.C., USA. [online] URL: http://www. climatescience.gov/Library/sap/sap4-4/final-report/

Cruce, T., and H. Holsinger. 2010. Climate change adaptation; what federal agencies are doing. PEW Center on Global Climate Change, Arlington, Virginia, USA.

D'Amato, A. W., J. B. Bradford, S. Fraver, and B. J. Palik. 2011. Forest management for mitigation and adaptation to climate change: insights from long-term silviculture experiments. Forest Ecology and Management 262:803-816. http://dx.doi.org/10.1016/j.foreco.2011.05.014

Danter, K. J., D. L. Griest, G. M. Mullins, and E. Norland. 2000. Organizational change as a component of ecosystem management. Society and Natural Resources 13:537-547. http://dx.doi.org/10.1080/08941920050114592
Davis, C. 2006. Western wildfires: a policy change perspective. Review of Policy Research 23(1):115-127. http:// dx.doi.org/10.1111/j.1541-1338.2006.00188.x

deLeon, P., and L. deLeon. 2002. What ever happened to policy implementation? An alternative approach. Journal of Public Administration Research and Theory 12(4):467-492. http://dx.doi.org/10.1093/oxfordjournals.jpart.a003544

Dilling, L., and E. Failey. In press. Managing carbon in a multiple use world: Implications of land-use decision making for carbon sequestration. Global Environmental Change.

Dilling, L., and M. C. Lemos. 2011. Creating usable science: opportunities and constraints for climate knowledge use and their implications for science policy. Global Environmental Change 21(2):680-689. http://dx.doi.org/10.1016/j.

gloenvcha.2010.11.006

Dillman, D. A. 2000. Mail and internet surveys: the Tailored Design Method. Second edition. John Wiley \& Sons, New York, New York, USA.

Dovers, S. 2009. Normalizing adaptation. Global Environmental Change 19:4-6. http://dx.doi.org/10.1016/j. gloenvcha.2008.06.006

Ellenwood, M. S., L. Dilling, and J. B. Milford. 2012. Managing United States public lands in response to climate change: a view from the ground up. Environmental Management 49:954-967. http://dx.doi.org/10.1007/

s00267-012-9829-2

Failey, E. L., and L. Dilling. 2010. Carbon stewardship: land management decisions and the potential for carbon sequestration in Colorado, USA. Environmental Research Letters 5(2). http://dx.doi.org/10.1088/1748-9326/5/2/024005

Government Accountability Office (GAO). 2007. Agencies should develop guidance for addressing the effects on federal land and water resources. Government Accounting Office, Washington, D.C., USA. [online] URL: http://www.gao.gov/ products/GAO-07-863

Government Accountability Office (GAO). 2009. Climate change adaptation: strategic federal planning could help government officials make more informed decisions. Government Accounting Office, Washington, D.C., USA. [online] URL: http://www.gao.gov/products/GAO-10-113

Interagency Climate Change Adaptation Task Force (ICCATF). 2011. Federal actions for a resilient nation: progress report of the interagency climate change adaptation task force. ICCATF, Washington, D.C., USA.

Jantarasami, L. C., J. J. Lawler, and C. W. Thomas. 2010. Institutional barriers to climate change adaptation in U.S. national parks and forests. Ecology and Society 15(4): 33. 
[online] URL: http://www.ecologyandsociety.org/vol15/iss4/ $\underline{\operatorname{art} 33 /}$

Joyce, L. A., G. M. Blate, S. G. McNulty, C. I. Millar, S. Moser, R. P. Neilson, and D. L. Peterson. 2009. Managing for multiple resources under climate change: national forests. Environmental Management 44:1022-1032. http://dx.doi. org/10.1007/s00267-009-9324-6

Koontz, T. M., and J. Bodine. 2008. Implementing ecosystem management in public agencies: lessons from the U.S. Bureau of Land Management and the Forest Service. Conservation Biology 22(1):60-69. http://dx.doi.org/10.1111/ j.1523-1739.2007.00860.x

Leiserowitz, A. 2006. Climate change risk perception and policy preferences: the role of affect, imagery, and values. Climatic Change 77(1-2):45-72. http://dx.doi.org/10.1007/ s10584-006-9059-9

Leiserowitz, A., E. Maibach, C. Roser-Renouf, and N. Smith. 2011. Global warming's six Americas, May 2011. Yale University and George Mason University, New Haven, Connecticut, USA.

Logar, N. J., and R. T. Conant. 2007. Reconciling the supply of and demand for carbon cycle science in the U.S. agricultural sector. Environmental Science and Policy 10(1):75-84. http:// dx.doi.org/10.1016/j.envsci.2006.10.006

McDermott, C. L., B. Cashore, and P. Kanowski. 2009. Setting the bar: an international comparison of public and private forest policy specifications and implications for explaining policy trends. Journal of Integrative Environmental Sciences 6(3):217-237. http://dx.doi.org/10.1080/19438150903090533

Mehta, R., and E. Sivadas. 1995. Comparing response rates and response content in mail versus electronic surveys. Journal of the Market Research Society 4(37):429-440.

Moritz, C., J. L. Patton, C. J. Conroy, J. L. Parra, G. C. White, and S. R. Beissinger. 2008. Impact of a century of climate change on small-mammal communities in Yosemite National Park, USA. Science 322(5899):261-264. http://dx.doi. org/10.1126/science. 1163428

Moser, S. C., and J. A. Ekstrom. 2010. A framework to diagnose barriers to climate change adaptation. Proceedings of the National Academy of Sciences 107(51):22026-22031. http://dx.doi.org/10.1073/pnas.1007887107.

Murphy, P. R., J. Daley, and D. R. Dalenberg. 1991. Exploring the effects of postcard pre-notification on industrial firms' response to mail surveys. Journal of the Market Research Society 33(4):335-345.

National Research Council (NRC). 2010. Adapting to the impacts of climate change: America's climate choices: panel on adapting to the impacts of climate change. National
Academies Press, Washington, D.C., USA. [online] URL: http://www.nap.edu/catalog.php?record id=12783

Paolo, A. M., G. A. Bonaminio, C. Gibson, T. Partridge, and K. Kallail. 2000. Response rate comparisons of e-mail and mail-distributed student evaluations. Teaching and Learning in Medicine 12(2):81-84. http://dx.doi.org/10.1207/ S15328015TLM1202_4

Reiners, D. 2012. Institutional effects on decision making on public lands: an interagency examination of wildfire management. Public Administration Review 72(2):177-186. http://dx.doi.org/10.1111/j.1540-6210.2011.02486.x

Ryan, M. G., S. R. Archer, R. Birdsey, C. Dahm, L. Heath, J. Hicke, D. Hollinger, T. Huxman, G. Okin, R. Oren, J. Randerson, and W. Schlesinger. 2008. Land resources. Pages 75-120 in The effects of climate change on agriculture, land resources, water resources, and biodiversity in the United States. Report by the U.S. Climate Change Science Program and the Subon Global Change Research. Washington, DC., USA.

Sabatier, P. 2005. From policy implementation to policy change: a personal odyssey. Reform and Change in Higher Education 8(1):17-34. http://dx.doi.org/10.1007/1-4020-3411-3 2

Sarewitz, D., and R. A. Pielke, Jr. 2007. The neglected heart of science policy: reconciling supply of and demand for science. Environmental Science \& Policy 10:5-16. http://dx. doi.org/10.1016/j.envsci.2006.10.001

Schofield, J. 2001. Time for a revival? Public policy implementation: a review of the literature and an agenda for future research. International Journal of Management Reviews 3(3):245-263. http://dx.doi.org/10.1111/1468-2370.00066

Schofield, J. 2004. A model of learned implementation. Public Administration 82(2):283-308. http://dx.doi.org/10.1111/ j.0033-3298.2004.00395.x

Sheehan, K. B. 2001. E-mail survey response rates: a review. Journal of Computer-Mediated Communication 6(2):0. http:// dx.doi.org/10.1111/j.1083-6101.2001.tb00117.x

Sheehan, K. B., and M. G. Hoy. 1999. Using e-mail to survey internet users in the United States: methodology and assessment. Journal of Computer-Mediated Communication 4(3). http://dx.doi.org/10.1111/j.1083-6101.1999.tb00101.x

Sheehan, K. B., and S. J. McMillan. 1999. Response variation in e-mail surveys: an exploration. Journal of Advertising Research 39(4):45-54.

Smit, B., I. Burton, J. Klein, and J. Wandel. 2000. An anatomy of adaptation to climate change and variability. Climatic Change 45(1):233-251.

Smith, J. B., and W. R. Travis. 2010. Adaptation to climate change in public lands management. Resources for the Future 
Issue Brief 10-04. [online] URL: http://www.rff.org/ publications/pages/publicationdetails.aspx? publicationid=21027

Spittlehouse, D., and R. Stewart. 2003. Adaptation to climate change in forest management. BC Journal of Ecosystems and Management 4(1).

Steelman, T. A., and S. M. McCaffrey. 2011. What is limiting more flexible fire management--public or agency pressure? Journal of Forestry 109(8):454-461.

Taylor, S., and P. Lynn 1998. The effect of a preliminary notification letter on response to a postal survey of young people. Journal of the Market Research Society 2 (40):165-178.

Theoharides, K., G. Barnhart, and P. Glick. 2009. Climate Change Adaptation across the Landscape: a survey offederal and state agencies, conservation organizations and academic institutions in the United States. The Association of Fish and Wildlife Agencies, Defenders of Wildlife, The Nature Conservancy, and The National Wildlife Federation, Merrifield Virginia, USA.

Tongco, M. D. C. 2007. Purposive sampling as a tool for informant selection. Ethnobotany Research \& Applications 5:147-158.

Tribbia, J., and S. C. Moser. 2008. More than information: what coastal managers need to plan for climate change. Environmental Science \& Policy 11(4):315-328. http://dx.doi. org/10.1016/j.envsci.2008.01.003

U.S. Fish and Wildlife Service (USFWS). 2010. Rising to the urgent challenge: strategic plan for responding to accelerating climate change. U.S. Fish and Wildlife Service, Washington, D.C., USA. [online] URL: http://www.fws.gov/ home/climatechange/pdf/CCStrategicPlan.pdf

West, J. M., S. H. Julius, P. Kareiva, C. Enquist, J. J. Lawler, B. Petersen, A. E. Johnson, and M. R. Shaw. 2009. U.S. natural resources and climate change: concepts and approaches for management adaptation. Environmental Management 44 (6):1001-1021. http://dx.doi.org/10.1007/s00267-009-9345-1

Wise, C. R., and C. M. Freitag. 2002. Balancing accountability and risk in program implementation: the case of national fire policy. Journal of Public Administration Research and Theory 12(4):493-523. http://dx.doi.org/10.1093/oxfordjournals.jpart. a003545

Wood, R. S. 2006. The dynamics of incrementalism: subsystems, politics, and public lands. Policy Studies Journal 34(1):1-16. http://dx.doi.org/10.1111/j.1541-0072.2006.00153. 
Appendix 1. Survey questions.

1. What type(s) of physical and biological management challenges does your office currently face? (Please check all that apply)

$\square$ Erosion

$\square$ Flooding

$\square$ Wetland Loss

$\square$ Air Quality

$\square$ Water Quality

$\square$ Climate Change

$\square$ Noise or Light Pollution

$\square$ Fire Management

$\square$ Species and Habitat Management

$\square$ Restoration from Fire or Other Disturbance

$\square$ Other (please specify)

2. What type(s) of other management challenges does your office currently face? (Please check all that apply)

$\square$ Stakeholder Conflicts

$\square$ Development of Adjacent Lands

$\square$ Lack of Funding

$\square$ Personnel Constraints

$\square$ Unpermitted Access on Closed Areas

$\square$ Participation in Unauthorized Activities

$\square$ Permitting Decisions

$\square$ Conflicting Mandates

$\square$ Other (please specify)

3. Which three of the issues listed in Questions $1 \& 2$ (physical, biological or other challenges) would you judge to be the most challenging for your office at present? (Please list in order of perceived priority)

1.

2.

3. 
4. How would you rate the severity of the top management challenge (\#1 in Question 3)? Please consider "severity" in terms of environmental and/or social/economic impacts.

The Top Management Challenge in My Office is:

$\square$ Not Serious at All

$\square$ Slightly Problematic

$\square$ Moderate

$\square$ Severe

$\square$ Very severe

5. Based on your knowledge and views, how might climate change impact public lands that are specifically managed by your office? Even if you have not previously considered the potential impacts of climate change on the public lands managed by your office, please offer your best estimate.

\begin{tabular}{|l|l|l|l|l|l|l|}
\hline & $\begin{array}{l}\text { Very Low } \\
\text { Possibility }\end{array}$ & $\begin{array}{l}\text { Low } \\
\text { Possibility }\end{array}$ & $\begin{array}{l}\text { Moderate } \\
\text { Possibility }\end{array}$ & $\begin{array}{l}\text { High } \\
\text { Possibility }\end{array}$ & $\begin{array}{l}\text { Don't } \\
\text { Expect to } \\
\text { Change }\end{array}$ & $\begin{array}{l}\text { Don't } \\
\text { Know }\end{array}$ \\
\hline $\begin{array}{l}\text { Increased Local Air } \\
\text { Temperatures }\end{array}$ & & & & & \\
\hline $\begin{array}{l}\text { Increased Local Water } \\
\text { Temperatures }\end{array}$ & & & & & & \\
\hline $\begin{array}{l}\text { Changes in Local Runoff } \\
\text { Timing }\end{array}$ & & & & & & \\
\hline More Local Flooding & & & & & & \\
\hline Less Local Flooding & & & & & \\
\hline More Frequent Local Storms & & & & & \\
\hline Less Frequent Local Storms & & & & & & \\
\hline $\begin{array}{l}\text { Changes in Local Spawning } \\
\text { Times of Species }\end{array}$ & & & & & & \\
\hline $\begin{array}{l}\text { Decreases in Local Water } \\
\text { Quality }\end{array}$ & & & & & & \\
\hline $\begin{array}{l}\text { Decrease in Local Water } \\
\text { Quantity }\end{array}$ & & & & & & \\
\hline $\begin{array}{l}\text { Increase in Local Potential for } \\
\text { Catastrophic Wildfire }\end{array}$ & & & & & & \\
\hline $\begin{array}{l}\text { Positive Impacts on Local } \\
\text { Ecosystems }\end{array}$ & & & & & & \\
\hline $\begin{array}{l}\text { Negative Impacts on Local } \\
\text { Wildlife }\end{array}$ & & & & & & \\
\hline Negative Impacts on Local & & & & & & \\
\hline
\end{tabular}




\begin{tabular}{|l|l|l|l|l|l|l|}
\hline Recreation & & & & & & \\
\hline Positive Impacts on Local & & & & & & \\
Recreation & & & & & & \\
\hline Negative Impacts on Local & & & & & & \\
Permittees & & & & \\
Negative Impacts on Nearby & & & & & \\
\hline $\begin{array}{l}\text { Positive Impacts on Nearby } \\
\text { Communities }\end{array}$ & & & & & & \\
\hline Other (please specify) & & & & & & \\
\hline
\end{tabular}

6. What, if any, changes has or will your office make in your management plans in response to climate change? (Please check all that apply)

$\square$ Update Flood Risk Maps

$\square$ Provide Additional Information / Educational Materials to the Public

$\square$ Changes in Locations of Activities Allowed

$\square$ Inventorying Greenhouse Gas Emissions (From Vehicles, Buildings etc.)

$\square$ Limiting / Reducing Emissions (From Vehicles, Buildings etc.)

$\square$ Reducing the Intensity of Land Use

$\square$ Changes in Types of Activities Allowed

$\square$ Forest Thinning/ Fuel Reduction

$\square$ Additional Measures to Protect Wildlife

$\square$ No Change in Response to Climate Change

$\square$ Other (please specify)

7. Has your local office developed strategies or plans to deal with the potential impacts from climate change?

$\square$ Yes, Plan is Currently Being Developed

$\square$ Yes, Plan is Being Carried Out

$\square$ No

$\square$ Don't Know

8. Which of the following statements regarding climate change do you agree with most?

$\square$ Climate change is real and already happening now 
$\square$ Climate change is probably happening and we will start seeing impacts in the near future

$\square$ Climate change may become a problem in the longer term future

$\square$ Climate change is probably not happening now and will not cause problems in the future

9. In your opinion, how serious is the problem of climate change?

$\square$ Not Serious at All

$\square$ Somewhat Serious

$\square$ Serious

$\square$ Very Serious

$\square$ Don't Know

10. How well informed do you feel you are about climate change?

$\square$ Well Informed

$\square$ Moderately Informed

$\square$ Not Well Informed

$\square$ Not at All Informed

$\square$ Don't Know

11. From your perspective, what are the most important factors preventing you from planning for adaptation to climate change? (Please rank your top three choices with 1 being the most important)

\begin{tabular}{|l|l|l|l|}
\hline & 1 & 2 & 3 \\
\hline Budget Constraints & & & \\
\hline Conflicting Mandates & & & \\
\hline Lack of Information at Relevant Scales & & & \\
\hline Lack of Specific Agency Direction & & & \\
\hline Lack of Useful Information & & & \\
\hline Not a High Priority in My Office & & & \\
\hline Personnel Constraints & & & \\
\hline Stakeholder Conflicts & & & \\
\hline Uncertainty in Available Information & & & \\
\hline Other (Please Specify) & & & \\
\hline
\end{tabular}


12. Whether or not your office has already taken action to prepare for the possible impacts of climate change, how much of a hurdle do you perceive the following issues to be in planning for climate change? (Please check one box per possible reason)

\begin{tabular}{|l|l|l|l|}
\hline & Big Hurdle & $\begin{array}{c}\text { Small } \\
\text { Hurdle }\end{array}$ & $\begin{array}{c}\text { Not a } \\
\text { Hurdle }\end{array}$ \\
\hline Lack of Public Awareness or Demand to Take Action & & & \\
\hline $\begin{array}{l}\text { Insufficient Staff Time to Get Informed About Issue, } \\
\text { Gather Relevant Information }\end{array}$ & & & \\
\hline Available Science is at the Wrong Scale & & & \\
\hline Lack of Perceived Importance to Public & & & \\
\hline Science is Difficult to Understand & & & \\
\hline $\begin{array}{l}\text { Insufficient Staff Resources to Analyze and Assess } \\
\text { Relevant Information }\end{array}$ & & & \\
\hline Legal Pressures to Maintain Status Quo & & & \\
\hline Not a High Priority in My Office & & \\
\hline $\begin{array}{l}\text { Lack of Social Acceptability of Strategies } \\
\text { That Take Global Warming into Account }\end{array}$ & & & \\
\hline Lack of Perceived Solution Options & & & \\
\hline Science is Too Uncertain & & & \\
\hline Budget Constraints & & & \\
\hline $\begin{array}{l}\text { No Legal Mandate to Take Global Warming Impacts } \\
\text { Into Account }\end{array}$ & & & \\
\hline Currently Pressing Issues are All-consuming & & & \\
\hline Opposition from Stakeholder Groups & & & \\
\hline Lack of "Best Available Science" & & & \\
\hline
\end{tabular}

13. Some actions taken in response to predicted changes in climate are similar to, or the same as, plans that are already in place for alternative reasons. For example, forest thinning is sometimes considered adaptation to climate change but often takes place for alternative reasons as well. To what degree will climate change adaptation plans differ from prior management plans?

$\square$ No Change

$\square$ Differ Slightly

$\square$ Differ Significantly

$\square$ Don't Know

$\square \mathrm{N} / \mathrm{A}$

14. Which Federal land agency do you currently work for? (choose all that apply)

$\square \mathrm{BLM}$ 
$\square$ US Forest Service

$\square$ National Park Service

$\square$ US Fish and Wildlife Service

$\square$ Other (please specify)

15. Which of the following best describes the position you fill in your agency?
$\square$ Planner
$\square$ Field Practitioner/ Technician
$\square$ Executive / Director
$\square$ Park / Forest Ranger
$\square$ Office Support
$\square$ Forest Supervisor
$\square$ Wildlife Manager
$\square$ Engineer
$\square$ Water Resources Manager
$\square$ Environmental Specialist
$\square$ Field Manager
$\square$ Staff Scientist
$\square$ Public Outreach / Education
$\square$ Recreation Planner / Technician / Specialist
$\square$ Other (please specify)

16. In an average week, approximately what percentage of your work deals with land management issues?

I spend the following amount of my time each week dealing with land management issues:

$\square$ None

$\square$ Under $20 \%$ (up to 1 day/week)

口 $20-50 \%$ (approx. $1-2.5$ days/ week)

口 50-75\% (approx. $2.5-4$ days/ week)

$\square$ Over $75 \%$ (more than 4 days/ week) 
17. How old are you?

18. Gender

$\square$ Male

$\square$ Female

19. Your race/ethnicity (Select one or more)

$\square$ White (nonhispanic)

$\square$ Asian / Pacific Islander

$\square$ Native American

$\square$ Black

$\square$ Hispanic

$\square$ Other

20. What is the highest level of education you have completed?

$\square$ Less Than 12th Grade (No Diploma)

$\square$ High School Graduate or Equivalent

$\square$ Some College, No Degree

$\checkmark$ Associate's Degree

$\square$ Bachelor's Degree

$\square$ Graduate or Professional Degree

21. If applicable, what was your major in college?

$\square$ Biological Sciences

$\square$ Physical Sciences

$\square$ Social Sciences

$\square$ Business

$\square$ Engineering

$\square$ Humanities 
22. How many years have you been employed by your agency?

23. How many years have you held the current position in which you are now employed?

24. Where is your office located?

State:

25. Which type of office do you work in?

$\square$ Regional Office

$\square$ District Office

$\square$ Research Station

$\square$ State Office

$\square$ Field Office

$\square$ Supervisors Office

$\square$ Other (please specify) 